\title{
INNOVATIVE HRD PRACTICES IN IT SECTOR ITS INFLUENCE ON
}

\section{EMPLOYEES PERFORMANCE}

\section{PL. VISALAKSHI}

Assistant Professor, Department of Commerce, Loyola College, Nungambakkam, Chennai, Tamil Nadu, India

\section{ABSTRACT}

In recent time the IT services industry is investing heavily in HRD practices aiming at the better performance of employees working in their concern. As IT sector involves knowledge workers, there should be relief for their stress. In order to reduce their conflicts, frustration and anomies different methods of HRD practices are used. So it is essential to analyse whether it has impact on their performances. The research is conducted to analyse the influence of HRD practices on employee's performance in selected five IT firms located in Chennai city. The data was collected from 125 IT employees evenly 25 employees from each firm. The sample was selected randomly from employees working in the firm. Method of sampling was convenient sampling. Detailed questionnaire was given to the respondents to collect the data required. Statistical tools used are correlation and chi-square. In the result it was identified that there is positive relationship between HRD practices and employee performances

KEYWORDS: Knowledge Workers, Stress Management, Frustration, Anomies, Human Capital \& Sustainable Employability

Received: Apr 18, 2019; Accepted: May 09, 2019; Published: Jun 10, 2019; Paper Id.: IJHRMRJUN201923

\section{INTRODUCTION}

Chennai a city in INDIA has many notable sectors like software, automobile, construction, many young people in and around Tamil Nadu looking for job in IT sectors. Most of the IT companies in Chennai collaborated with international and domestic companies

Chennai is contributing business of about $14 \%$ of the total export of software in INDIA. In IT related service chennai stands in second largest place as largest export of IT related service. In Chennai "tidel park " is the largest IT service. So to analyse the impact of HRD practices in it sector become inevitable. Hence it become essential to study about the impact of innovative HRD practices in IT sector

\section{Sample Size}

Sample size taken for the study is 125 , from 5 leading IT company's .25 employees were chosen randomly from each company and data were collected from them. Simple random non probability convenience sampling was used in the study. Samples are taken from the following IT firms

- INAUTIX

- $\quad$ SIMENS

- $\quad$ CAPGEMINI INDIA 
- $\quad$ HEXAWARE

- $\quad$ VIRTUSA POLARIS

\section{Innovative HRD Practices Followed in IT Sector}

IT sector is the work is defined as the most efficient way accomplishing a task in a monotonous procedure. these practices have been done for a period of time by people which involves more fatigue. By adoption of certain best practices the performance of people working there can be improved. human resource management always helps in attaining competitive advantage through people working there.

Innovative HRD practise can bring effective results in providing security for employment, herring best people, information sharing, self-management team and payment based on performance, power lunch, free refreshments in working hours and sustainable employment. To achieve organisational goal the management should follow some strategies, by doing this the employee will work more efficiently. By doing innovative HRD practices the employee will work with fullest satisfaction. with the help of these practices the workers are not tired, it will help for the organisation to achieve better heights. It will create safe, happy and healthy working place for the employee and work for the organisation with full effort.

Good innovative practices in the organisation can achieve desired at the earliest. sharing the important information in IT sector like objectives of the company, management details, policies, employee data can help for others for references. Through these technique employees can ignite creative endeavour in the work. this may also help in people to work more efficiently. Hence the employee resource is called as Human Capital.

\section{REVIEW OF LITERATURE}

According to Crossan and Apaydin 2010, HRM policies and practices are new and suitable for different organisations according to their needs, so for each organisation HR Practices differs. .

In next phase the authors labelled the changes taken in HR practices as innovative HRD practices because they are suitable for their organisation which is not followed by any other organisation hence it is called as innovative HRD practices

Agarwala 2003, in his study he identified 14 HR areas for hiring employees, performance appraisal polices, training and development polices for the development of HR department and the methods followed to retain the employees in their organisation.

The main theoretical idea in this part of the literature is that HR policies and practices contribute to organizational performance as they increase the performance, satisfaction and commitment of employees if these policies and practices form bundles or systems. This means that the different HR policies and practices that organizations can apply, for example aimed at attracting new personnel, training employees, facilitate career paths, etc, need to be offered as a coherent set of instruments. What follows from this is that focusing on a single instrument is less effective than having a combination of instruments that are aimed at the same goal. According to this logic, organizations that apply instruments with contrasting goals (i.e. combining teamwork with individual pay) function poorer. What this literature furthermore shows is that to be effective, these policies and practices need to be aligned internally (they need to fit together) and aligned externally (they need to fit the organization's environment) (Huselid 1995, MacDuffie and Kochan 1995). 
Koster 2011 analyse, The answer why this is more effective lies for a large part in the answer that employees are able, willing and knowing to do their work if HR instruments are aligned .

\section{Statement of the Problem}

- To analysis the employee's performance with regard to innovative HRD practices followed in it sector

- To evaluate the attrition rate change after innovative HRD practices

- To find the relationship between innovative HRD practices and employee stress management

\section{Significance of the Study}

IT sector invests huge amount in maintaining human resources in their concern. It is essential to find the influence of Innovative HRD practices on employee's performances

\section{Need for the Study}

The study throws light on the impact of Innovative HRD practices on employees performance and also helps to identify the best practices followed in IT firms

\section{Objectives of the Study}

- To study the effectiveness of innovative HRD practices in IT sector

- To analysis the innovative HRD practices and employee performance

- To study the relationship between innovative HRD practices and employee stress management

- To evaluate the employees attrition rate after following innovative HRD practices

\section{RESEARCH METHODOLOGY}

The research design of the study is analytical method. In this research the researcher tries to analysis the HRD practices and their impact on employees' performance in IT firms in Chennai city. The researcher instrument used for the present study is a well-structured questionnaire. With respect to impact of HRD practices, convenience sampling approach has been found acceptable hence for the current study convenient sampling method was used.

\section{DATA COLLECTION}

The data was collected by using convenient sampling and analysed using correlation, and chi-square analysis and percentage analysis. 


\section{DATA ANALYSIS AND INTERPRETATION}

\section{Demographic Profile}

Table 1: Demographic Profile

\begin{tabular}{|l|l|c|c|}
\hline \multicolumn{1}{|c|}{ Variables } & \multicolumn{1}{|c|}{ Option } & Frequency & \% \\
\hline \multirow{2}{*}{ Gender } & Male & 60 & 48 \\
& Female & 65 & 52 \\
\hline \multirow{3}{*}{ Age } & Below 25 years & Open ended question & 25 \\
& 25-35 years & (Scale variables) & 65 \\
& Above 35 years & 64 & 10 \\
\hline \multirow{2}{*}{ Marital status } & Married & 61 & 51 \\
& Unmarried & 46 & 49 \\
\hline \multirow{3}{*}{ Qualification } & UG & 58 & 46 \\
& PG & 21 & 17 \\
\hline
\end{tabular}

Sources: primary data

From the above table it is inferred that female respondents (52\%) are more than male respondents (42\%). In term of age majority of respondents belong to 25-35 years. Regarding marital status unmarried are more than married in the sample taken for the study. 58\% of the respondent possesses PG degree.

Table 2: Sample Details

\begin{tabular}{|l|c|c|c|c|c|}
\hline $\begin{array}{c}\text { Company } \\
\text { Name }\end{array}$ & $\begin{array}{c}\text { No of } \\
\text { Employees }\end{array}$ & Male & Percentage & Female & Percentage \\
\hline Inautix & 25 & 15 & $25 \%$ & 10 & $15 \%$ \\
\hline Simens & 25 & 12 & $20 \%$ & 13 & $20 \%$ \\
\hline Capgemini & 25 & 10 & $16 \%$ & 15 & $23 \%$ \\
\hline Hexaware & 25 & 13 & $22 \%$ & 12 & $19 \%$ \\
\hline Virtusapolaris & 25 & 10 & $17 \%$ & 15 & $23 \%$ \\
\hline \multicolumn{1}{|c|}{ Total } & $\mathbf{1 2 5}$ & $\mathbf{6 0}$ & & $\mathbf{6 5}$ & \\
\hline
\end{tabular}

\section{DATA ANALYSIS AND INTERPRETATION}

\section{Demographic Profile}

Table 3: Demographic Profile

\begin{tabular}{|c|c|c|c|}
\hline Variables & Option & Frequency & $\%$ \\
\hline \multirow{2}{*}{ Gender } & Male & 60 & 48 \\
& Female & 65 & 52 \\
\hline \multirow{3}{*}{ Age } & Below 25 years & Open ended question & 25 \\
& 25-35 years & (Scale variables) & 65 \\
& Above 35 years & 64 & 10 \\
\hline \multirow{2}{*}{ Marital status } & Married & 61 & 51 \\
& Unmarried & 46 & 49 \\
\hline \multirow{2}{*}{ Qualification } & UG & 58 & 37 \\
& PG & 21 & 46 \\
& Others & & \\
\hline
\end{tabular}

Sources: primary data

From the above table it is inferred that female respondents $(52 \%)$ are more than male respondents $(42 \%)$. In term of age majority of respondents belong to 25-35 years. Regarding marital status unmarried are more than married in the sample taken for the study. 58\% of the respondent possesses PG degree. 
Table 4: Sample Details

\begin{tabular}{|c|c|c|c|c|c|}
\hline $\begin{array}{c}\text { Company } \\
\text { Name }\end{array}$ & No of Employees & Male & Percentage & Female & percentage \\
\hline Inautix & 25 & 15 & $25 \%$ & 10 & $15 \%$ \\
\hline Simens & 25 & 12 & $20 \%$ & 13 & $20 \%$ \\
\hline Capgemini & 25 & 10 & $16 \%$ & 15 & $23 \%$ \\
\hline Hexaware & 25 & 13 & $22 \%$ & 12 & $19 \%$ \\
\hline Virtusapolari & 25 & 10 & $17 \%$ & 15 & $23 \%$ \\
\hline Total & $\mathbf{1 2 5}$ & $\mathbf{6 0}$ & & $\mathbf{6 5}$ & \\
\hline
\end{tabular}

\section{CORRELATION ANALYSIS}

Employee's Perception and Innovative HRD Practices in IT Sector

Table 5

\begin{tabular}{|c|c|c|c|c|c|c|}
\hline Variables & $\mathbf{N}$ & R value & P value & Relationship & Significant & Result \\
\hline $\begin{array}{c}\text { Innovative HRD } \\
\text { practices- } \\
\text { employees } \\
\text { performance }\end{array}$ & 125 & $0.949^{* *}$ & 0.000 & Positive & Significant & Rejected \\
\hline $\begin{array}{c}\text { Innovative HRD } \\
\text { practices- } \\
\text { employee's job } \\
\text { satisfaction }\end{array}$ & 125 & $0.928^{* *}$ & 0.000 & Positive & Significant & Rejected \\
\hline $\begin{array}{c}\text { Innovative HRD } \\
\text { practices- low } \\
\text { attrition rate }\end{array}$ & 125 & $0.921^{* *}$ & 0.000 & Positive & Significant & Rejected \\
\hline $\begin{array}{c}\text { Innovative HRD } \\
\text { practices- stress } \\
\text { balances }\end{array}$ & 125 & $0.927^{* *}$ & 0.000 & Positive & Significant & Rejected \\
\hline $\begin{array}{c}\text { Innovative HRD } \\
\text { practices-work } \\
\text { life balance }\end{array}$ & 125 & $0.915^{* *}$ & 0.000 & Positive & Significant & Rejected \\
\hline \multicolumn{2}{|c|}{ Source: primary data; $* *$ correlation is significant at the 0.01 level (2 tailed) } &
\end{tabular}

As the $\mathrm{p}$ values are lesser than the significant value (0.01) in all the above cases, the null hypothesis is rejected. There is high positive and significant correlation between the employees perception and Innovative HRD practices in IT sector. Out the five factors relating to Innovative HRD practices, employees perception on their performance has more relationship.

Table 6: Gender and Preference on Innovative HRD Practices

\begin{tabular}{|l|l|l|l|l|l|l|l|l|}
\hline Gender & \multicolumn{2}{|l|}{ Satisfied } & \multicolumn{2}{l|}{ Not satisfied } & \multicolumn{2}{|c|}{ Neutral } & \multicolumn{2}{|c|}{ Total } \\
\hline & $\mathrm{O}$ & $\mathrm{E}$ & $\mathrm{O}$ & $\mathrm{E}$ & $\mathrm{O}$ & $\mathrm{E}$ & $\mathrm{O}$ & $\mathrm{E}$ \\
\hline Male & 40 & 43.2 & 20 & 12 & 0 & 4.8 & 60 & 60 \\
\hline Female & 50 & 46.8 & 5 & 13 & 10 & 5.2 & 65 & 65 \\
\hline Total & $\mathbf{9 0}$ & $\mathbf{9 0}$ & $\mathbf{2 5}$ & $\mathbf{2 5}$ & $\mathbf{1 0}$ & $\mathbf{1 0}$ & $\mathbf{1 2 5}$ & $\mathbf{1 2 5}$ \\
\hline
\end{tabular}

Source: primary data

By applying chi-square test, the analysis was made to check the relationship between gender and preference on Innovative HRD practices

Test of statistic $x^{\wedge} 2=\left((o-E)^{\wedge} 2\right) \div E$ 
$=19.9426$

Level of significance $=0.05$

Degree of freedom $=2$

Critical value $=5.991$

Calculated value is more than the table value. So null hypothesis is rejected. Hence there is relationship between gender and preference on Innovative HRD practices.

\section{FINDINGS}

- There is significant relationship between innovative HRD practices and employee performances.

- There is positive correlation between innovative HRD Practices and job satisfaction

- Due to innovative HRD practices the attrition rate of employees are considerably reduced.

- The employees stress levels is reduced due to innovative HRD practices.

- With the help of innovative HRD practices employees have perfect work life balance

- Comparatively female employees prefer innovative HRD practices than Male employees in IT sector

\section{SUGGESTION}

- As innovative HRD practices have great impact on employees working in IT industry more new HRD practices should be implemented frequently.

- As IT industry involves more knowledge workers the employees must be stress free.

- Innovative HRD practices can be used to reduce the fatigue level of employees.

\section{CONCLUSIONS}

The respondents have given positive feedback about innovative HRD practices. To attract and retain talent in organisation, HRD plays an important and inevitable role. Innovative HRD practices increase employee satisfaction, employee productivity. Various other improvements result due to innovative HRD practices. In micro level it has minimum impact in organisational efficiency. Small firms are similar to medium size firms but large firms have more impact due to innovative HRD practices. larger firms are able to implement these initiative fully and able to spend more money over larger number of people .

\section{REFERENCES}

1. Agarwala, T. (March 2003). Innovative Human Resource Practices and organizational commitment: an empirical investigation. International Journal of Human Resource Management .

2. Bhatnagar, P. S. (Jan-Mar 2008). Turnarouns @ Motorola India-Mobile Devices Business through the HR Lever. Vikalpa Vol.33 No. 1 .

3. Bing, H. K. (2011). Friend or Foe? The Promise and Pitfalls of Using Social Networking Sites for HR Decisions. J Bus Psychol. 
4. Carmen CameloOrdaz, M. F. (April 2008). Top Management Team's vision and human resurce management practices in innovative spanish companies. The International Journal of Human Resource Management Vol 19 No. 4.

5. Chand, M. (March 2010). The impact of HRM practices on service quality, customer satisfaction and Performance in the Indian hotel industry.The International Journal of Human Resource Management, Vol. 21 No. 4.

6. Cho, P. G. (June 2010). The impact of human resource management practices on intention to leave of Employees in the service industry in India: the mediating role of organizational commitment. The International Journal of Human Resource Management. 
